\title{
E-SIP: Website-Based Scheduling Information System to Increase the Effectivity of Lecturer's Performance and Learning Process
}

\author{
Khoirul Anam ${ }^{*}$, Beni Asyhar ${ }^{1}$, Kundharu Saddhono², Bagus Wahyu Setyawan² \\ ${ }^{1}$ Faculty of Education and Teachers' Training, Institut Agama Islam Negeri (IAIN) Tulungagung, Jl. Mayor Sujadi No. 46, \\ Kudusan, Plosokandang, Kec. Kedungwaru, Kabupaten Tulungagung, Jawa Timur 66221, Indonesia \\ ${ }^{2}$ Faculty of Teacher Training and Education, Universitas Sebelas Maret, J1. Ir Sutami No. 36 A, Jebres, Surakarta, Kota \\ Surakarta, Jawa Tengah 57126, Indonesia
}

Corresponding Author Email: chasna_choir@iain-tulungagung.ac.id

https://doi.org/10.18280/isi.260303

Received: 5 August 2020

Accepted: 22 December 2020

\section{Keywords:}

scheduling information system, elektronik sistem informasi penjadwalan (E-SIP), website-based scheduling, effectivity of lecturers' performance, effectivity of learning process

\begin{abstract}
The development of internet and information technology made a system to the practical, effective, and efficient. One of the impacts is ease to make scheduling information system in university. This research is research and development (R\&D) models which have aim to develop the website-based scheduling information system to increase the effectivity of lecturer's performance and learning process in IAIN Tulungagung. E-SIP program develop by using software development life cycle in term of waterfall model. Waterfall model was selected because it was easy and efficient. This system development consisted of system need analysis, system design, implementation, testing, dissemination, and maintenance. Data collecting system using literature review, field study, and interview. Furthermore, data also collected from questionnaire scores of E-SIP validations conducted by the validator and respondents, in terms of admins. After doing some development phase and trial, the ESIP was developed and ready to use to make scheduling process in IAIN Tulungagung. ESIP possibly runs with using any browser supporting the java-script system. The development result of E-SIP is in terms of login page for users in three levels. The first level is Super Admin which is responsible to input all databases needed for E-SIP. The second level is Department Admin, which is responsible to arrange the individual schedule of departments. The third level is Faculty Admin, which only able to see the schedule arranged by Department Admin. The similarity of all levels is to print and see the schedule. The advantage of E-SIP is that the scheduling system is able to be controlled by online and performed simultaneously at one time as well as to check overlapping or nonautomatic schedules in the website. Besides, the disadvantage happens when there is a bug or an error resulting in that the system does not function properly and needs to be immediately resolved.
\end{abstract}

\section{INTRODUCTION}

An educational system is supposed to be implemented effectively and efficiently if all education elements are managed, arranged, and synergistic. Some points considered as criteria of the effective and efficient system are a synergy between higher authority policies, learning systems, and learning processes conducted by educational agents [1]. Formal learning in higher educations is provided by a system integrated to facilities including adequate classrooms, learning media, and learning sources. These contribute to creating effective learning processes. The role of lecturers as functional agents who are responsible to conduct learning processes is crucial. They need to have integrity and discipline in conducting their duties [2]. Besides, a course scheduling system is also fundamental in learning processes. The scheduling system is an activity conducted to plot schedule and classroom in each course [3]. It is used to manage the learning process effectively and avoid overlapping schedules between courses. Moreover, there are some important aspects to be paid attention while making a scheduling system including the availability of classrooms, lecturers, number of credits, and number of students [4]. These aspects are compulsorily concerned by stakeholders before plotting the schedule at the beginning of the semester.

In the process of arranging a schedule, there are some steps conducted. First, an officer who is responsible to arrange a schedule coordinates with heads of department and Vice Dean for Academic to determine subjects, number of classes, number of credits, and lecturers in the related semester. Second, the officer considers the availability of facilities and classrooms. The more number of rooms usually makes the officer easy to arrange the schedule because there are many options to place schedule components such as days, hours, rooms, lecturers, subjects, number of credits, and participants [5]. Third, the officer arranges and divides the schedule by considering effective hours in each day. Effective time management in learning also concerns to avoid the accumulation of hours or classes beyond effective hours. Fourth, a tool used also affects the officer's performance in arranging the schedule. It includes a manual tool such as paper, or desktop or website-based computer application.

Arranging course schedules is a routine activity conducted by higher education management [6]. At the beginning of the 
semester, the manager of departments or faculties is in collaboration to arrange a fast, accurate, and efficient course schedule. Fast means that the course scheduling process is no need for a long time, the schedule finishes on time before the deadline. Accurate means that the level of accuracy is high, there is no overlapping schedules, and there is the availability to check the requirement of minimum and maximum teaching workload. Efficient means that the schedule is beneficial according to the needs.

Faculty of Education and Teachers' Training (FTIK), Institut Agama Islam Negeri (IAIN) Tulungagung is one of the biggest faculties, consisting of 12 departments and approximately 10.000 students. The number of departments and students indirectly affects the course scheduling process. Some difficulties and constraints occasionally occur due to overlapping schedules, credits, and lecturers in the course scheduling process. The existence of the Academic Information System (SIAKAD) in terms of SIAKAD version 1 , version 2 , and version 3 , at the institution level still fails to detect overlapping schedules inputted by departments. This condition still happens until now. This system used a computer-based application namely Microsoft Office Access. It seems manual and is unable to detect overlapping schedules, check minimum and maximum limit of teaching workload [7]. Besides, the limitation of personnel and officers who arrange the schedule also obstructs the course scheduling process. Moreover, it is occasionally needed accompaniment from the Vice Dean for Academic.

With the development of technology and information, some sophisticated tools are recognized. The application existing in the computer is available to be used by 1 person or more. Besides, computer applications are also used to communicate data between computers in rooms, buildings, cities, or even counties. Communication between computers is now known as the internet or interconnection network. By this development, developing applications to deal with course scheduling is crucial [8]. The application developed is possibly used both individually and collectively to decrease workload relatively taking a toll on energy and mind.

Currently, there are many developed scheduling applications. These applications include desktop and websitebased applications. Dekstop-based scheduling application is an individual application. It is no need for an internet connection and limited to a certain operating system [9]. Website-based scheduling application is an application requiring a browser and internet connection. Each application has both strengths and weaknesses. Moreover, an online academic information system application was developed by Nurelasari [10] by including the course scheduling menu and integrated into website-based. By this application, civitas academics could access the schedule online without limitation of space and time. Besides, it also provided user safety, help to determine the distribution of certain courses, and help students in programming courses through the internet. It was also able to check the overlapping schedule with reference to scheduling elements.

Another course scheduling information system was developed by Ikbal and Mauluddin [11]. This system possibly 1) made a limitation of time in collecting teaching availability occasionally obstructing the scheduling process, 2) organized, checked, and verified teaching availability as well as determined days, sessions, locals, and classes to each available hour; 3 ) counted and knew the number of credits fulfilled by lecturers; 4) decreased paper usage; 5) minimized human error;
6) made the schedule arranged fast.

Furthermore, a desktop-based application for course scheduling system developed by Rizan [12]. It helped the academic unit to arrange course scheduling, create a fast, accurate, and efficient report, and improve the officer's performance. However, its usage is still limited and needs installation. In contrast, a scheduling information system using the Genetic Algorithm also developed by Hussein and Hasoon [13]. It was able to automatically disorder the schedule based on its parameters. Genetic Algorithm was able to optimize the course scheduling process. On one hand, this application is able to easily disorder and arrange schedule automatically but tend to consume a long process to disorder when the parameters are a lot. Likewise, Noviasari et al. [14] applied Round Robin Algorithm System on a course scheduling system by conducting a case study in Universitas Multimedia Nusantara.

The scheduling system using software and application has been widely applied in the entire world. It is because of the need for an efficient, practical, and economical system that can arrange a fast and appropriate schedule. A learning system with a practical method developed by Abdullah et al. [15] using welch powell graph coloring algorithm to simplify course scheduling in Universitas Malikussaleh. Besides, a scheduling system using a cloud manufacturing method developed by Zhou et al. [16]. It is possibly used manually and automatically with the system. Besides, a scheduling system is also inseparable from time management or course effective hours. Hence, Shioura et al. [17] attempted to integrate the time controlling process in a scheduling system to be more effective.

Based on previous studies, the study assumes that the information system based on the desktop still needs installation in each computer, is only appropriate for a certain operation system, and unable to be used collaboratively. Besides, the information system based on the website is more flexible. It is no need installation and only using a browser and internet connection, it is able to be operated. Additionally, there is no limitation of space and time to operate this system. It is also possibly operated simultaneously while arranging a course schedule.

The information system for scheduling, both desktop, and website-based, has been able to solve the problem in arranging a course schedule which is time-consuming, complicated, and energy-consuming [18]. This schedule has been able to check overlapping schedule components and know the number of credits fulfilled by lecturers according to their status, but still failed to determine the minimum and maximum limitation of teaching workload according to lecturers' status and position. Hence, this study introduced an information system for website-based electronic scheduling or abbreviated as E-SIP. It is considered to be fast, accurate, efficient, and able to determine the minimum and maximum limitation of teaching workload based on lecturer status and position.

\section{METHOD}

This study was developmental research. A Scheduling Information System Application or E-SIP was developed using the software development life cycle model, in terms of waterfall. Waterfall was selected because it was easy and efficient. The steps of this study started with the process of collecting the data in terms of library research, field study 
using interview and observation, and a set of literature study. After that, the process of developing E-SIP system was conducted with reference to the data obtained in the intial study. This system development consisted of System Need Analysis, System Design, Implementation, Testing, Dissemination, and Maintenance [19]. It is drawn in the following Figure 1.

This study needed data and information concerning sources to develop the scheduling system. Sources were obtained from valid and credible references that later supported the discussion. Data collection technique used literature review, field study, and interview. The literature review was to study related theories and results of previous studies supporting the completion of scheduling system development. The study used sources from books, articles, and similar studies. systematic literature review (SLR) aims to contribute to the deconstruction of these and other myths that have emerged around e-learning, by approaching the research conducted in this regard in the last decade. This allowed for identifying the main study themes and research lines that provide scientific knowledge about the present and future of this educational technology $[20,21]$. The field study was to get information directly related to the data characteristic and existing policies in the location. It was conducted in the Faculty of Education and Teachers' Training (FTIK), IAIN Tulungagung, to get the information about how the system was used and problems occurred while the course scheduling process. The data was then analyzed to know if the system was able to be developed in making the scheduling process easier, faster, more accurate, and more efficient. Besides, the interview was carried out to people in connection to the course scheduling process, such as education personnel, department managers, and vice of dean for academics.
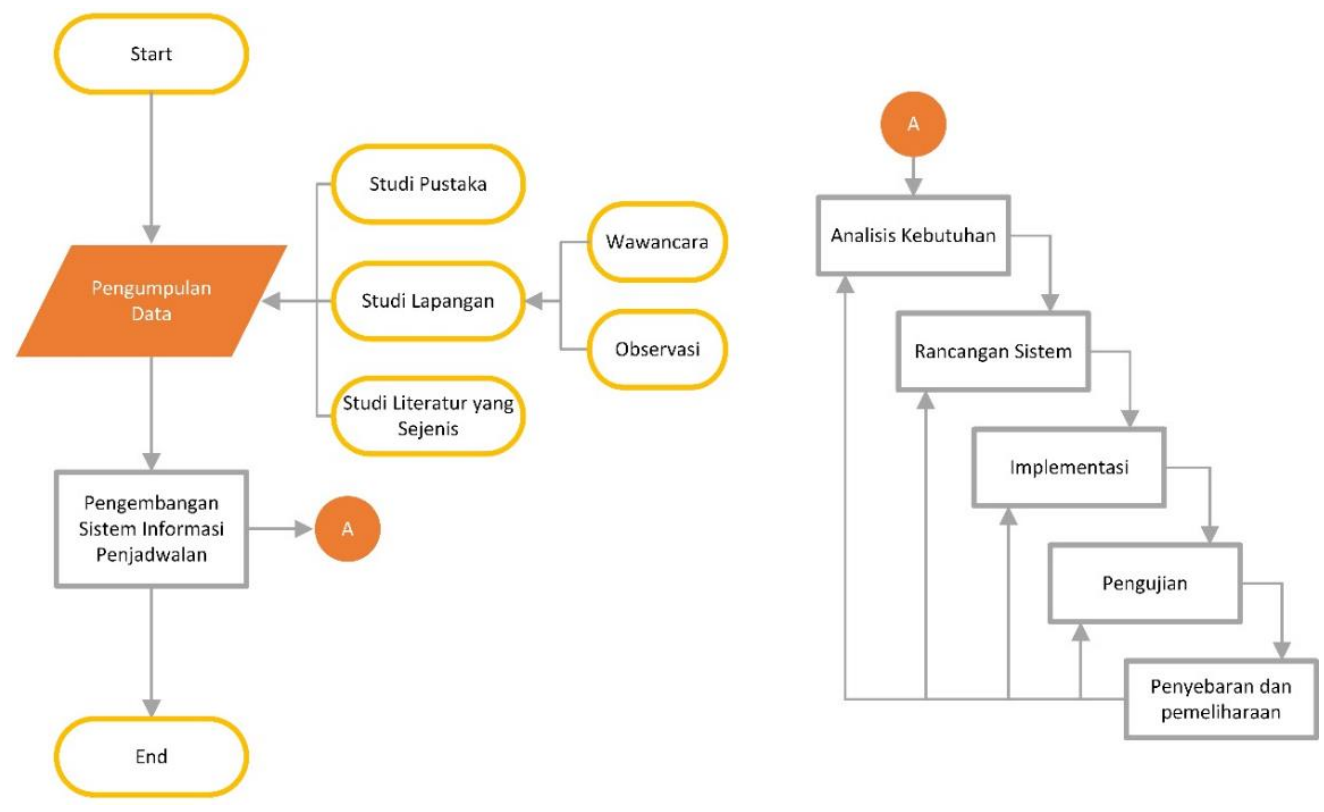

Figure 1. Developmental model of website-based scheduling information system

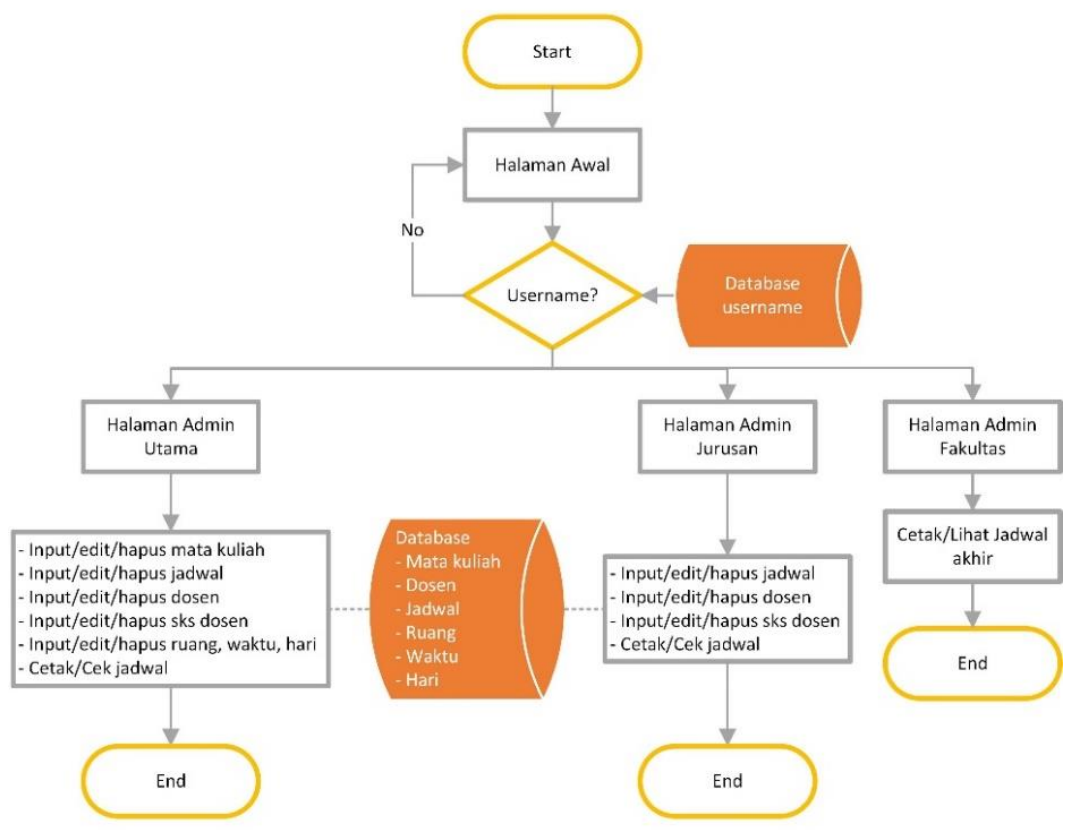

Figure 2. Scheduling information system flowchart 
The Scheduling information system consisted of three main parts, including initial display, schedule input display, and result display. The following Figure 2 reflected the flowchart, interface display design, and distribution design of developed system.

The E-SIP application was then analyzed to know its errors and weaknesses. Testing E-SIP was conducted in two steps, including expert and field tests. The expert test was conducted to get the validity of the product from a validator. The validator is one of the programming experts from IAIN Tulungagung. Meanwhile, the field test on the testing subject was to know the feasibility of the system made. The testing subject consisted of programming experts and target users. They were 3 department admins since it involved three departments.

The data used qualitative and quantitative data. The quantitative data were obtained from questionnaire scores of E-SIP validation conducted by the validator and respondents, in terms of admins. Besides, qualitative data were critics and suggestions given by the validator and respondents.

The instrument was a close questionnaire. The score obtained dealt with Likert scale on positives question with the score range of 5, 4, 3, 2, and 1 (Table 1) [22].

Data analysis technique was percentage analysis to process the data of expert and field tests. The formula was based on Arikunto [23], as follows. a) Formula for processing a single datum per question

$$
P=\frac{x}{x_{i}} \times 100 \%
$$

Note:

$\mathrm{P} \quad=$ Percentage

$\mathrm{X} \quad=$ Repondents' answers for a question

$\mathrm{x}_{\mathrm{i}}=$ Minimum answers from total number of questions.

b) Formula to process the whole data

$$
P=\frac{\sum x}{\sum x_{i}} \times 100 \%
$$

Note:

$\mathrm{P} \quad=$ Percentage

$\sum \mathrm{x}=$ Total number of respondent's answers for $\mathrm{a}$ question

$\sum \mathrm{x}_{\mathrm{i}}=$ Total number of maximum answers from total number of questions

The result of calculation and analysis of data related feasibility program e-sip then measured the percentage its feasibility. Indicators feasibility of program e-sip can be seen in Table 2.

Table 1. Likert score scale

\begin{tabular}{cccccc}
\hline Alternative Scale & $\mathbf{1}$ & $\mathbf{2}$ & $\mathbf{3}$ & $\mathbf{4}$ & $\mathbf{5}$ \\
\hline 1 & Very unfeasible & Unfeasible & Less feasible & Feasible & Very feasible \\
\hline 2 & Very inappropriate & Inappropriate & Less appropriate & Appropriate & Very appropriate \\
\hline 3 & Very improper & Improper & Less proper & Proper & Very proper \\
\hline 4 & Really disagree & Disagree & Less disagree & Agree & Really agree \\
\hline
\end{tabular}

Table 2. Feasibility level criteria

\begin{tabular}{ccc}
\hline $\begin{array}{c}\text { Percentage } \\
(\%)\end{array}$ & $\begin{array}{c}\text { Feasibility } \\
\text { Level }\end{array}$ & Description \\
\hline $76-100$ & Feasible & Feasible / No need revision \\
\hline $51-70$ & $\begin{array}{c}\text { Feasible } \\
\text { Enough }\end{array}$ & $\begin{array}{c}\text { Feasible enough / No need } \\
\text { revision }\end{array}$ \\
\hline $26-50$ & Less Feasible & $\begin{array}{c}\text { Less feasible / Need some } \\
\text { revision }\end{array}$ \\
\hline$<26$ & Unfeasible & Unfeasible / Total revision \\
\hline
\end{tabular}

\section{RESULTS AND DISCUSSION}

\subsection{Description of E-SIP}

The scheduling information system or E-SIP is an information system developed to check the course scheduling system if it is overlapping or not. In general, E-SIP is still unable to make the course schedule automatically by inputting some constraints. In particular, the researcher believes that ESIP is able to decrease scheduling problems related to overlapping schedules. A part of the E-SIP display is developed by HTML, CSS, AJAX, and Bootstrap. Besides, it uses the MySQL database. Meanwhile, the database and E-SIP display are connected by PHP. E-SIP is operated using a local server to do testing with the XAMPP application. It is also able to be operated using hosting and a particular domain.

One of the great benefits of scheduling lecturers' subjects is that the Chair of the Study Program in scheduling the subjects of the regular lecturers and extraordinary lecturers can quickly and accurately [24]. The need to create a scheduling system for lecturer subjects to support the smoothness of lectures so that it can make it easier for the Chair of the Study Program and students as well as other parties concerned [25].

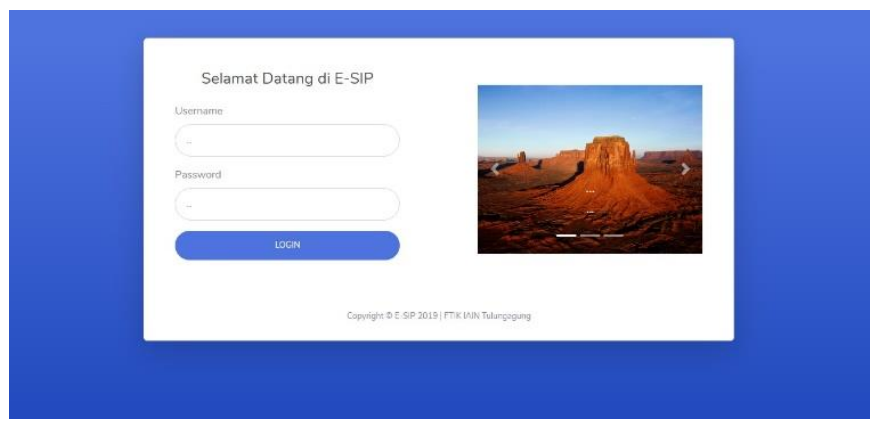

Figure 3. Login page

The initial page of E-SIP is a login page for users, divided into three levels. The first level is Super Admin, to input all databases needed for E-SIP. The second level is Department Admin, to make an independent schedule of departments and input it into the E-SIP to be included in the checking process on overlapping schedules. The third level is the Faculty Admin This level is only able to see scheduling results made by department admins. The similarity of all levels is the ability to print and see the schedule made. The login page display can be seen in Figure 3. 


\subsection{E-SIP Display}

E-SIP has some main parts in terms of displays. At the design stage, the system / interface starts with the phases, including: the design of the login page, dashboard page in Figure 4; lecturer page in Figure 5; course page display in Figure 6; classroom page display in Figure 7; course distribution page display in Figure 8; course scheduling page display in Figure 9; and course recapitulation page in Figure 10 . These parts are in the following.
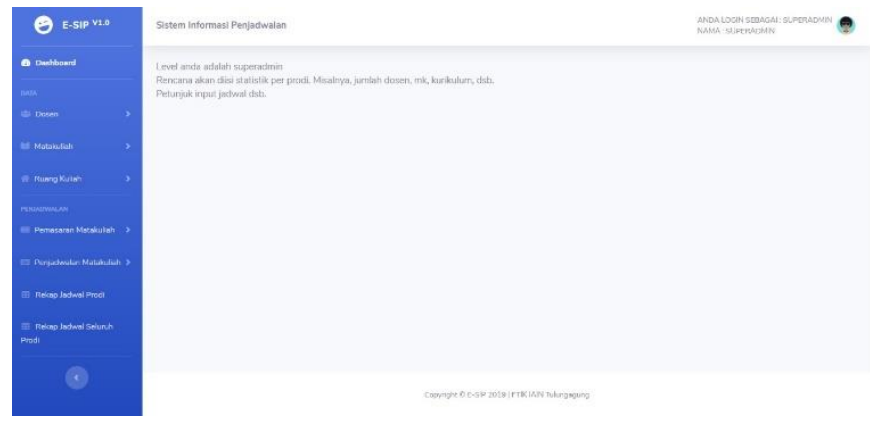

Figure 4. Dashboard page

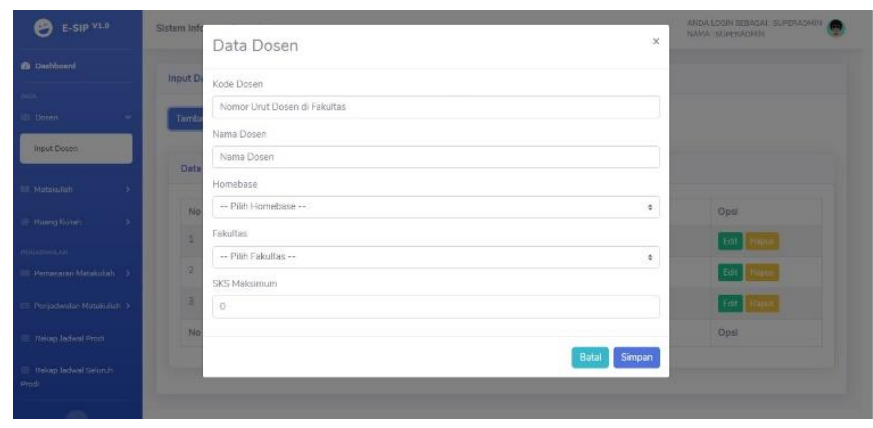

Figure 5. Lecturer page

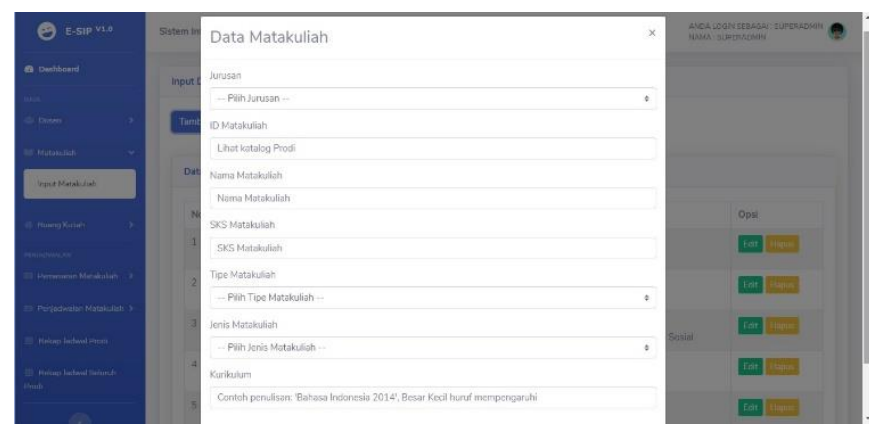

Figure 6. Course page

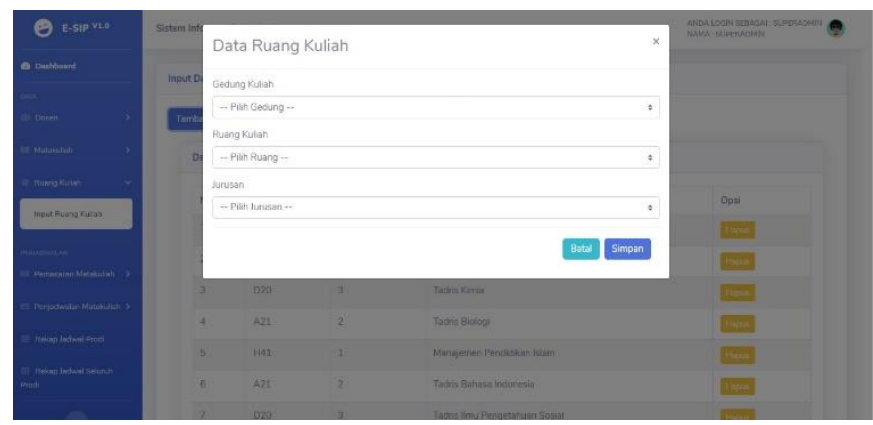

Figure 7. Classroom page

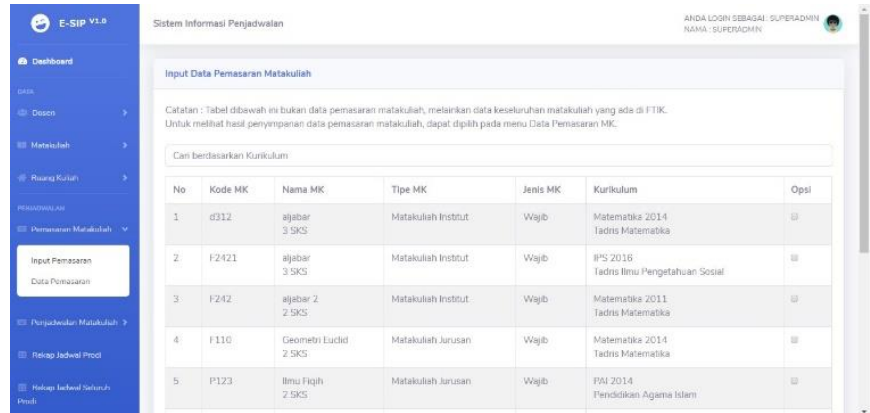

Figure 8. Course distribution page

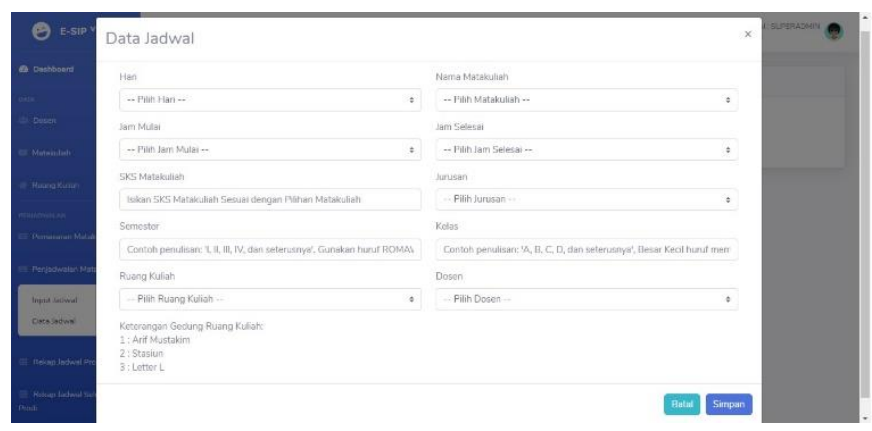

Figure 9. Course scheduling page

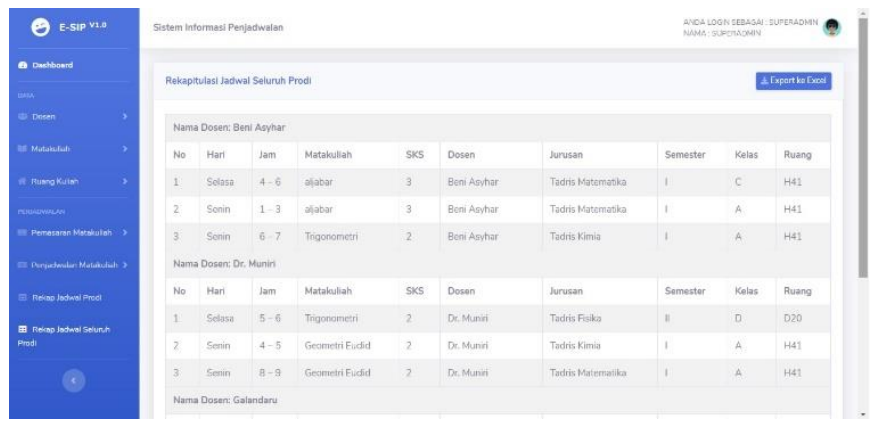

Figure 10. Course recapitulation page

\subsection{Data display and data analysis}

The data obtained as validated by the programming expert and field test with the subject of department admins. The explanation is in the followings.

\subsubsection{Data and analysis of validation results}

The data and analysis results obtained from the programming expert namely Galandaru Swalaganata, M.Si who is a lecturer of Mathematic Education in IAIN Tulungagung. The validation result from Mr. Galandaru Swalaganata, M.Si. represented in the Table 3. Also the critics and suggestion from the validator of Media expert shown in Table 4.

Based on the data obtained as validated by the programming expert, the data analysis of each aspect is in the followings.

Application. The indicators of application aspect include if the application is easy to be installed in the computer. Furthermore, the other factors are application is not easy to stop, the application is easy to use, the buttons are as expected, and there is no delay while opening the application or in the transition from one task to another [26]. The programming expert gives the score orderly of $5,5,4,3,5,5$ or $90 \%$, which is categorized as valid. 
Table 3. Validation results

\begin{tabular}{|c|c|c|c|c|}
\hline No & Assessment Aspects & Maximum Score & Validation Score & $\%$ \\
\hline \multicolumn{5}{|c|}{ Application } \\
\hline 1 & E-SIP application is easy to be installed. & 5 & 5 & 100 \\
\hline 2 & E-SIP application is not easy to be down/ stop while being used. & 5 & 5 & 100 \\
\hline 3 & E-SIP application is not complicated to be used. & 5 & 4 & 80 \\
\hline 4 & Each button in E-SIP application gives the right output. & 5 & 3 & 60 \\
\hline 5 & There is no too long delay while running the application. & 5 & 5 & 100 \\
\hline 6 & Screen movement on the application is smooth or there no lag. & 5 & 5 & 100 \\
\hline \multicolumn{5}{|c|}{ Graphic } \\
\hline 7 & The use of font (types, size, and color) is clear and appropriate. & 5 & 5 & 100 \\
\hline 8 & Layout design is interesting (coloring and image illustration). & 5 & 4 & 80 \\
\hline 9 & Layout setting is balance and not overlapping. & 5 & 5 & 100 \\
\hline 10 & Color display used in E-SIP is clear and appropriate. & 5 & 5 & 100 \\
\hline 11 & Image display used in E-SIP supports words/terms. & 5 & 5 & 100 \\
\hline 12 & Font and background are not overlapping. & 5 & 4 & 80 \\
\hline 13 & Application icons are interesting. & 5 & 4 & 80 \\
\hline \multicolumn{5}{|c|}{ Feasibility of Content and Material } \\
\hline 14 & Words are easy to understand. & 5 & 4 & 80 \\
\hline 15 & Data displayed have been appropriate with the data in the database. & 5 & 5 & 100 \\
\hline 16 & Code is made orderly. & 5 & 4 & 80 \\
\hline 17 & Illustration, punctuation, and symbol are correct. & 5 & 4 & 80 \\
\hline \multirow[t]{2}{*}{18} & Language use is appropriate and easy to understand. & 5 & 5 & 100 \\
\hline & Total & 90 & 81 & 90 \\
\hline
\end{tabular}

Table 4. Critics and suggestions from programming expert

\begin{tabular}{|c|c|}
\hline No. & Critics and Suggestions \\
\hline 1. & $\begin{array}{l}\text { Fill the dashboard with the interesting information (for } \\
\text { example, number of lecturers, courses, and so forth). }\end{array}$ \\
\hline 2. & $\begin{array}{l}\text { Fix the display of course recap. It can be ordered based on } \\
\text { lecturers' names. }\end{array}$ \\
\hline 3. & Give clear guidelines for users, admins, and super admins. \\
\hline 4. & $\begin{array}{l}\text { It is better if the data are able to be exported to Ms. Excel } \\
\text { or PDF. }\end{array}$ \\
\hline
\end{tabular}

Graphic. The indicators of graphic aspect include the use of font, layout design, layout setting, color display, image display, not overlapping font and background, and interesting application icons. He gave the score orderly of 5, 4, 5, 5, 5, 4, 4 or $91.43 \%$, referring to valid application.

Feasibility. The content feasibility indicators include words used, data displayed, codes made, illustrations, punctuations, symbols, and language used. The programming expert gives the score orderly of $4,5,4,4,5$ or $88 \%$, reflected as valid.

\subsubsection{Data and analysis of field test validity result}

The questionnaire of field test is obtained from testing subject as much as 3 personnel of department admins in the Faculty of Education and Teachers' Training, IAIN Tulungangung. The data are drawn in the following Table 5 and 6 .

Based on Table 5, it is concluded that the score of field test on three admins is obtained as much as 167 out of 180 or 92.7\%. Thus, E-SIP is categorized as valid. Furthermore, critics and suggestion from users in field test can be seen in Table 6.

Table 5. Field test result

\begin{tabular}{ccccc}
\hline No & Assessment Aspects & Maximum Score & Validation Score & \% \\
\hline 1 & Color display used in E-SIP is clear and appropriate. & 15 & 14 & 93,33 \\
\hline 2 & Image display used in E-SIP supports words/terms searched. & 15 & 13 & 86,67 \\
\hline 3 & Transition containing in E-SIP is interesting. & 15 & 15 & 100 \\
\hline 4 & Display design of each page of E-SIP is interesting. & 15 & 14 & 93,33 \\
\hline 5 & Button design in E-SIP is interesting. & 15 & 14 & 93,33 \\
\hline 6 & Button in E-SIP is easy to use. & 15 & 14 & 93,33 \\
\hline 7 & Font used in E-SIP is clear and appropriate. & 15 & 13 & 86,67 \\
\hline 8 & E-SIP application is not complicated to use. & 15 & 13 & 86,67 \\
\hline 9 & Font and background are not overlapping. & 15 & 13 & 86,67 \\
\hline 10 & Language use in words /terms is easy to understand. & 15 & 14 & 93,33 \\
\hline 11 & This application is able to check whether course schedule is overlapping. & 15 & 100 \\
\hline 12 & Color display used in E-SIP is clear and appropriate. & 15 & 15 & 100 \\
\hline & Total & 180 & 167 & 92,7 \\
\hline
\end{tabular}

Table 6. Critics and suggestions from users

\begin{tabular}{cc}
\hline No. & Critics and Suggestion \\
\hline 1. & Home display for admin is less interesting. \\
2. & Give the guideline of using the application. \\
\hline
\end{tabular}

\subsection{E-SIP revision}

Regarding the validation results and field test, E-SIP is considered feasible to be used. There are some critics and suggestions related to E-SIP with reference to the programming expert and field test. As a consequence, the 
minor revisions are required.

\subsubsection{Revision based on programming expert}

The critics and suggestions from the programming expert are brought into the revision. The revisions of each critic and suggestion are the followings.

$>$ Fill the dashboard with the interesting information. This revision has been conducted as shown in Figure 11 (before the revision) and Figure 12 (after the revision).
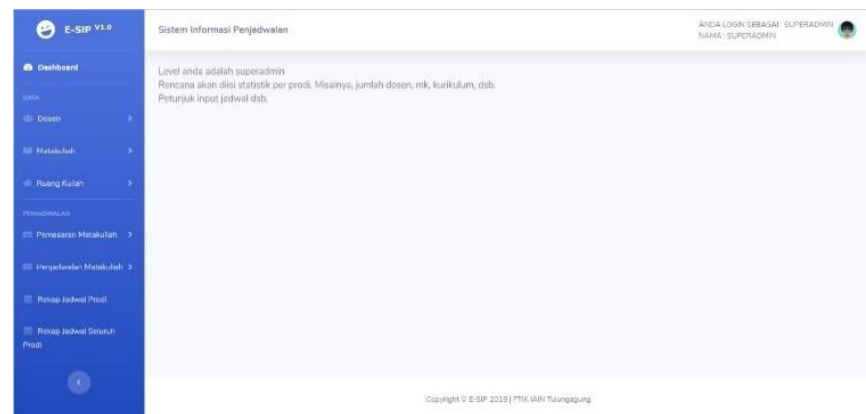

Figure 11. Display before revision a
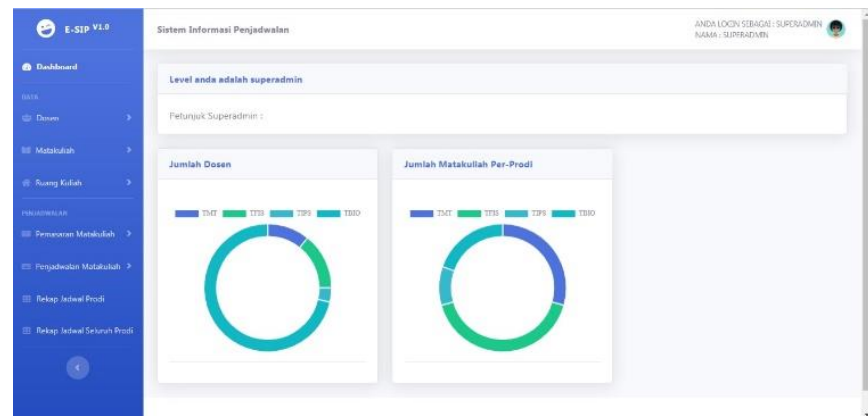

Figure 12. Display after revision a
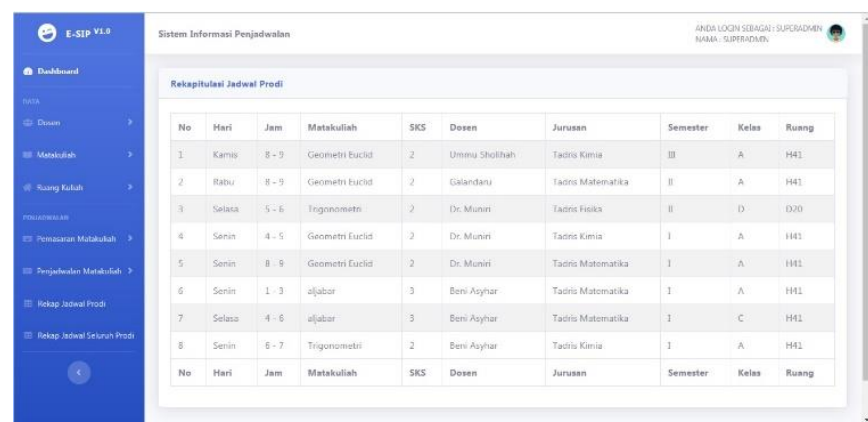

Figure 13. Display before revision $b$
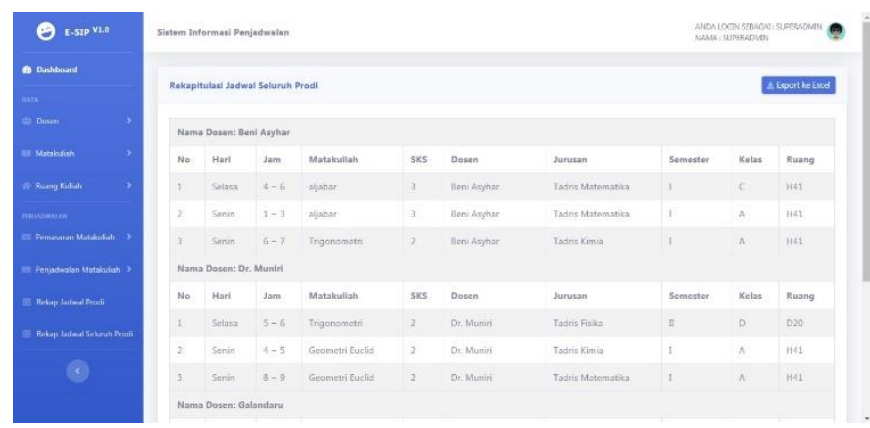

Figure 14. Display after revision b

Fix the display of course recap. This revision has been conducted as suggested by the expert. The course recap is order based on lecturers' names. The display before the revision is shown in Figure 13 while the display after the revision is drawn in Figure 14.

Give clear guidelines for users, admins, and super admins. The displays after the revision are represented in Figures 15,16 , and 17 .

$>$ It is good if the data are able to be exported to Ms. Excel. The display after the revision is reflected in Figure 18.

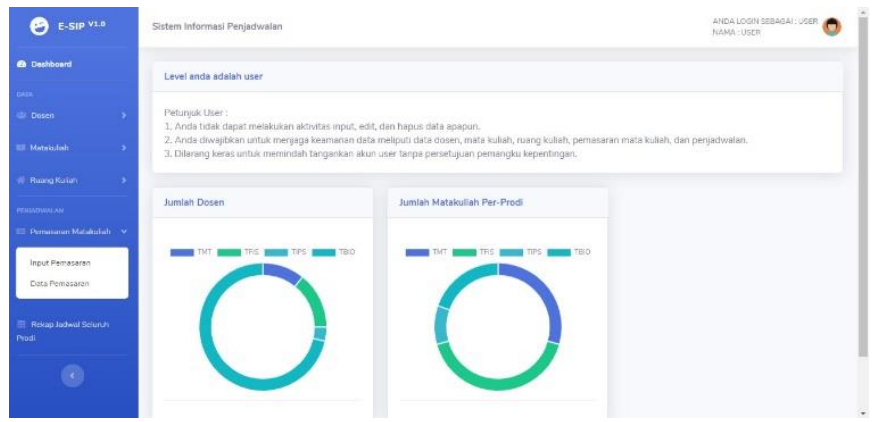

Figure 15. Adding guidelines for users
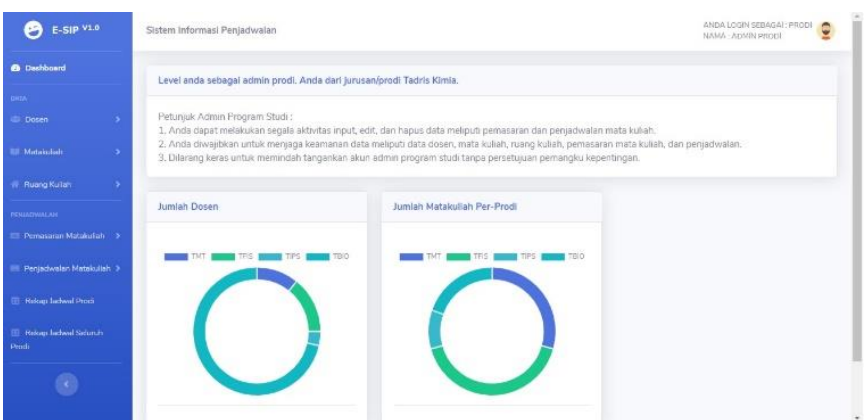

Figure 16. Adding guidelines for admin's department

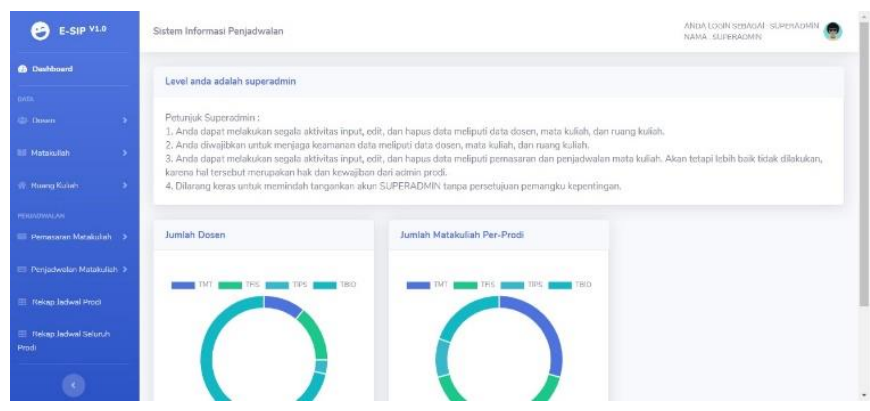

Figure 17. Adding guidelines for super admins

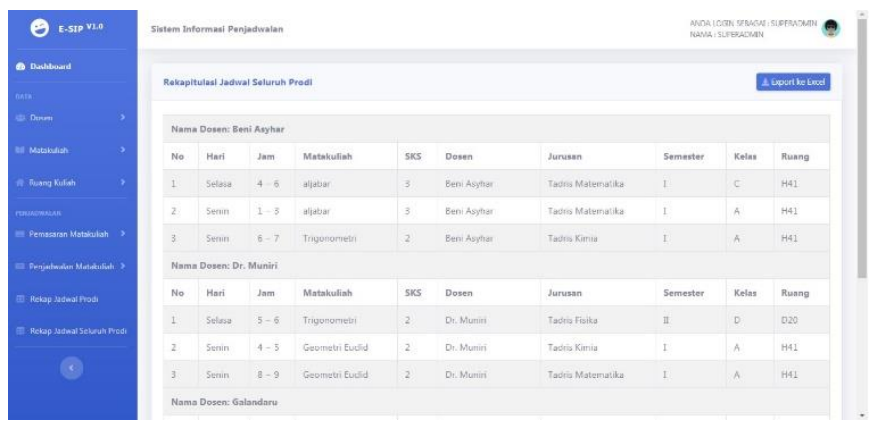

Figure 18. Adding menu of exporting the schedule to Ms. Excel

3.4.2 Revision based on field test

Based on field test result, E-SIP gets some critics and 
suggestions. Hence, the study revise E-SIP as the followings.

$>$ The admins claimed that home display for admin is less interesting. This critic has been executed as reflected in Figure 11 (before the revision) and Figure 12 (after the revision).

$>$ The admins suggested to give user guidelines. This suggestion has been conducted as reflected in Figure 15 (before the revision) and Figure 17 (after the revision).

\section{CONCLUSION}

E-SIP or Electronic Scheduling Information System developed through the developmental steps of the waterfall model is an information system with the ability to check overlapping schedule well and accurately. Besides, it also able to do basic functions of the information system including inputting, editing, deleting, and displaying the data as the developer's intention. Moreover, it is able to export the schedule into Ms. Excel.

E-SIP possibly runs with using any browser supporting the java-script system. The development result of E-SIP is in terms of login page for users in three levels. The first level is Super Admin. This level is responsible to input all databases needed for E-SIP. The second level is Department Admin. This level is responsible to arrange the individual schedule of departments as well as input it into the system so the super admin is able to check the overlapping schedules. The third level is Faculty Admin. This level is only able to see the schedule arranged by Department Admin. The similarity of all levels is to print and see the schedule.

E-SIP has been validated by the programming expert and passed field test on three department's admins. The result shows that E-SIP gets $90 \%$ score from the programming expert. In a consequence, E-SIP is considered valid and feasible to use. Besides, field test shows $92.7 \%$ score, indicating that E-SIP is valid and feasible to use.

\section{REFERENCES}

[1] Mason, L. (2018). Multiplicity in the digital era: Processing and learning from multiple sources and modalities of instructional presentations. Learning and Instruction, 57: 76-81. https://doi.org/10.1016/j.learninstruc.2018.03.004

[2] Bertram Gallant, T. (2017). Academic integrity as a teaching \& learning issue: From theory to practice. Theory into Practice, 56(2): 88-94. https://doi.org/10.1080/00405841.2017.1308173

[3] Khosiawan, Y., Park, Y., Moon, I., Nilakantan, J.M., Nielsen, I. (2019). Task scheduling system for UAV operations in indoor environment. Neural Computing and Applications, 31(9): 5431-5459. https://doi.org/10.1007/s00521-018-3373-9

[4] Peng, Z.P., Lin, J.P., Cui, D.L., Li, Q.R., He, J.G. (2020). A multi-objective trade-off framework for cloud resource scheduling based on the Deep Q-network algorithm. Cluster Computing, 23: 2753-2767. https://doi.org/10.1007/s10586-019-03042-9

[5] Sobaszek, Ł., Gola, A., Kozłowski, E. (2017). Application of survival function in robust scheduling of production jobs. In 2017 Federated Conference on Computer Science and Information Systems (FedCSIS), pp. 575-578. https://doi.org/10.15439/2017f276

[6] Skobelev, P.O., Simonova, E.V, Zhilyaev, A.A., Travin, V.S. (2017). Application of multi-agent technology in the scheduling system of swarm of earth remote sensing satellites. Procedia Computer Science, 103: 396-402. https://doi.org/10.1016/j.procs.2017.01.127

[7] van Duijnhoven, J., Aarts, M.P.J., Aries, M.B.C., Rosemann, A.L.P., Kort, H.S.M. (2019). Systematic review on the interaction between office light conditions and occupational health: Elucidating gaps and methodological issues. Indoor Built Environment, 28(2): 152-174. https://doi.org/10.1177/1420326x17735162

[8] Yang, H., Xiong, S., Frimpong, S.A., Zhang, M. (2020). A consortium blockchain-based agricultural machinery scheduling system. Sensors, 20(9): 2643. https://doi.org/10.3390/s20092643

[9] He, Y., Chen, Y., Lu, J., Chen, C., Wu, G. (2019). Scheduling multiple agile earth observation satellites with an edge computing framework and a constructive heuristic algorithm. Journal of Systems Architecture, 95: 55-66. https://doi.org/10.1016/j.sysarc.2019.03.005

[10] Nurelasari, E. (2020). Perancangan Sistem Informasi Akademik Pada Sekolah Menengah Pertama Berbasis Web. Komputika: Jurnal Sistem Komputer, 9(1): 67-73. https://doi.org/10.34010/komputika.v9i1.2243

[11] Ikbal, I., Mauluddin, S. (2018). Classroom booking information system integrated with course scheduling information system. In IOP Conference Series: Materials Science and Engineering. IOP Publishing, pp. 1-6. https://doi.org/10.1088/1757-899x/407/1/012163

[12] Rizan, O. (2016). Sistem Informasi Penjadwalan Dosen Ajar Studi Kasus: STMIK Atma Luhur. J. Nas. Teknol. dan Sist. Inf., 2(1): 65-74. https://doi.org/10.25077/teknosi.v2i1.2016.65-74

[13] Hussein, Q.M., Hasoon, A.N. (2017). Dynamic process scheduling using genetic algorithm. In 2017 Annual Conference on New Trends in Information \& Communications Technology Applications (NTICT), pp. 111-115. https://doi.org/10.1109/ntict.2017.7976116

[14] Noviasari, I., Rusli, A., Hansun, S. (2018). Penerapan Algoritma ACO untuk Penjadwalan Kuliah Pengganti pada Perguruan Tinggi (Studi Kasus: Program Studi Informatika, Universitas Multimedia Nusantara). Ultim. InfoSys Jurnal Ilmu Sistem Informasi, 9(2): 79-85 https://doi.org/10.31937/si.v9i2.1062

[15] Abdullah, D., Nurdin, Yaton, M., Sujatmiko, H., Kristanto, S.P., Nazmi, H., Sridanti, I.L., Suhendi, A., Hasibuan, A., Kurniawati, R., Harahap, D.E., Hutabarat, H.D., Sudarsana, I.K. (2019). Lecture scheduling system using welch powell graph coloring algorithm in informatics engineering departement of Universitas Malikussaleh. In Journal of Physics: Conference Series, 1363(1): $\quad 12074 . \quad$ https://doi.org/10.1088/1742$6596 / 1363 / 1 / 012074$

[16] Zhou, L.F., Zhang, L., Zhao, C., Laili, Y.J., Xu, L.D. (2018). Diverse task scheduling for individualized requirements in cloud manufacturing. Enterprise Information Systems, 12(3): 300-318. https://doi.org/10.1080/17517575.2017.1364428

[17] Shioura, A., Shakhlevich, N.V, Strusevich, V.A. (2018). Preemptive models of scheduling with controllable processing times and of scheduling with imprecise computation: A review of solution approaches. European Journal of Operational Research, 266(3): 795-818. 
https://doi.org/10.1016/j.ejor.2017.08.034

[18] Xu, K. (2020). Course selection guide, change analysis and development trend analysis of new college entrance examination reform. In International Conference on Modern Educational Technology and Innovation and Entrepreneurship (ICMETIE 2020), pp. 279-284. https://doi.org/10.2991/assehr.k.200306.122

[19] Kneuper, R. (2017). Sixty years of software development life cycle models. IEEE Annals of the History of Computing, 39(3): $41-54$ https://doi.org/10.1109/mahc.2017.3481346

[20] Valverde-Berrocoso, J., Garrido-Arroyo, M.D.C., Burgos-Videla, C., Morales-Cevallos, M.B. (2020). Trends in educational research about e-learning: A systematic literature review (2009-2018). Sustainability, 12(12): 5153. https://doi.org/10.3390/su12125153

[21] Conz, E., Magnani, G. (2020). A dynamic perspective on the resilience of firms: A systematic literature review and a framework for future research. European Management Journal, 38(3): 400-412. https://doi.org/10.1016/j.emj.2019.12.004

[22] Aprillia, A., Magdalena, N. (2018). Pengukuran Kualitas Layanan dalam Bidang Pendidikan Tinggi. Jurnal Manajemen $\quad$ Maranatha, 18(1): 11-22. https://doi.org/10.28932/jmm.v18i1.1092

[23] Kurniawan, A., Seminar, K.B., Iskandar, B.H., Nasution, S. (2015). Studi Kelayakan Inaportnet dan Strategi Pengembangan E-business di Pelabuhan Makassar. Warta Penelitian Perhubungan, 27(5): 345-356. https://doi.org/10.25104/warlit.v27i5.797

[24] Shofyan, M.I., Aziza, N., Rizaq, M.C., Farkhan, Agung Santoso, M., Cholili, A., Anam, K., Charisma, B., Muafa, A., Yuntarso, A. (2019). Expert system design for webbased lecturer scheduling. Journal of Physics: Conference $\quad$ Series, $1175(1)$ : 12119. https://doi.org/10.1088/1742-6596/1175/1/012119

[25] Habibi, M.R.M., Mohammadabadi, F., Tabesh, H., Vakili-Arki, H., Abu-Hanna, A., Eslami, S. (2019). Effect of an online appointment scheduling system on evaluation metrics of outpatient scheduling system: A before-after multicenter study. J. Med. Syst., 43(8): 281. https://doi.org/10.1007/s10916-019-1383-5

[26] Hak, T., Kovanda, J., Weinzettel, J. (2012). A method to assess the relevance of sustainability indicators: Application to the indicator set of the Czech Republic's Sustainable Development Strategy. Ecological Indicators, 17: 46-57. https://doi.org/10.1016/j.ecolind.2011.04.034 